\title{
Role of Livestock to Improve the Economy of Sota Border Community Based on Environment
}

\author{
Nurcholis ${ }^{1}$, Dirwan Muchlis ${ }^{3}$, Syetiel Maya Salamony ${ }^{4}$ \\ Animal Science Department \\ Universitas Musamus \\ Merauke, Indonesia \\ 1nurcholis@unmus.ac.id, 3muchlisdirwan@gmail.com, \\ ${ }^{4}$ syetielunmus60@gmail.com
}

\author{
Lilik Surmaryanti ${ }^{2}$ \\ Informatics Department \\ Universitas Musamus \\ Merauke, Indonesia \\ 2lilik@unmus.ac.id
}

\begin{abstract}
Sota communities mostly depend on local agricultural income. The purpose of this research is to know the role of business in the field of livestock to social level (welfare) in Sota District community in environmentally border area. The method used is a survey using questionnaires to 90 respondents selected by purposive random sampling on people who work as farmers and breeders. Primary and secondary data were analyzed descriptively. The results showed that the characteristics of livestock farmers belong to the age of productive, and experienced in the field of animal husbandry business. Average income of chicken breeders 156.000 IDR per month, besides the type of chicken farming business is highest in cultivated by local people tribe "Kanume". Various factors of constraints in livestock business in the border region is an environmental factor that gives the effect of lowering the interest of raising chickens due to the emergence of the type of disease. But in general livestock business has a positive impact to improve the economy of border communities.
\end{abstract}

Keywords: livestock; economy; local people border

\section{INTRODUCTION}

Sota is one of the villages directly adjacent to the new guinea Papua state, located in the sota district which is $80 \mathrm{~km}$ from the city of Merauke and as one of the tourist attractions. The population of Kampong Sota is 1,952 people based on the data report of village in 2017. The villagers of Sota are mostly farmers consisting of local farmers or "kanume" and xtransmigration farmers. The farmers in Sota village are divided into two, namely vegetable farmers for $\mathrm{x}$-transmigration residents and tubers farmers, bananas for local farmers. People in sota do not fully rely on the income of the economy on agriculture, efforts are made to increase incomes such as shops, food stalls, hunting and raising. Various types of livestock have long been used in rural farming activities, among others, to plow the land, transportation of agricultural products, and as a provider of fertilizer for the production of seasonal crops. In addition, livestock serves as a food provider (source of protein). Community effort other than agriculture which many cultivated in village sota is raising cattle, chickens, goats, pigs, and ducks. According to [5], chicken livestock business has become part of the farmer's cultivation system and a source of income households also have high socioeconomic value. In addition, the motivation of farmers who make livestock in the village as a Sota of life is very high up to $82.5 \%$ [7]. Livestock development undertaken by most border communities to improve welfare is traditional in accordance with local customs or cultures. Livestock business to improve the economy of the border community needs to be developed further, especially in the field of livestock, this is based on the potential of the village area Sota good for livestock business either ruminants or poultry. Potency of existing area village Sota includes the availability of animal feed and users of livestock. Availability of available feed such as forage, grazing land and agricultural waste. In addition, the other potential is the number of food stalls that accommodate the production of livestock. Based on the potential village background and the motivation of the community to raise livestock, there is a need for research related to the role of livestock business on the social level (welfare) in the Sota district community in the border area based on the environment.

\section{METHOD}

The method used is a survey using questionnaires to 90 respondents selected by purposive random sampling on people who work as farmers and breeders. Primary and secondary data were analyzed descriptively based on field facts.

\section{RESULT AND DISCUSSION}

The result of the research shows that the Sota villagers have superior professions which are varied, namely the profession as the farmers and the breeders reach $81.07 \%$, followed by $14.04 \%$ farmers, $3.4 \%$ breeders, $1.41 \%$ entrepreneurs, and $1.08 \%$ of the civil servants (PN). Mixed businesses (farmers and breeders) are the most sought after efforts by the Sota villagers to improve their economies, some of the most dominant mixed businesses between farmers and breeders are poultry. This is certainly related to the maintenance process and the benefits obtained more quickly when compared with the cultivation of large livestock species. Figure 1 shows the relationship of the community profession and livestock. But in addition to poultry type of cattle is the second choice to be sought as long-term savings. This is related to cattle productivity factors that are safer when compared with poultry associated with disease problems. cattles are more resistant to certain diseases than poultry and the price per cattle is more 
expensive, this is the reason why cattle become an alternative as long-term savings. In addition to savings and cultivated livestock business is used for the fulfillment of family nutrition. This is in line with the opinion of [11], that integrated agriculture with livestock is required by obtaining its meat products.

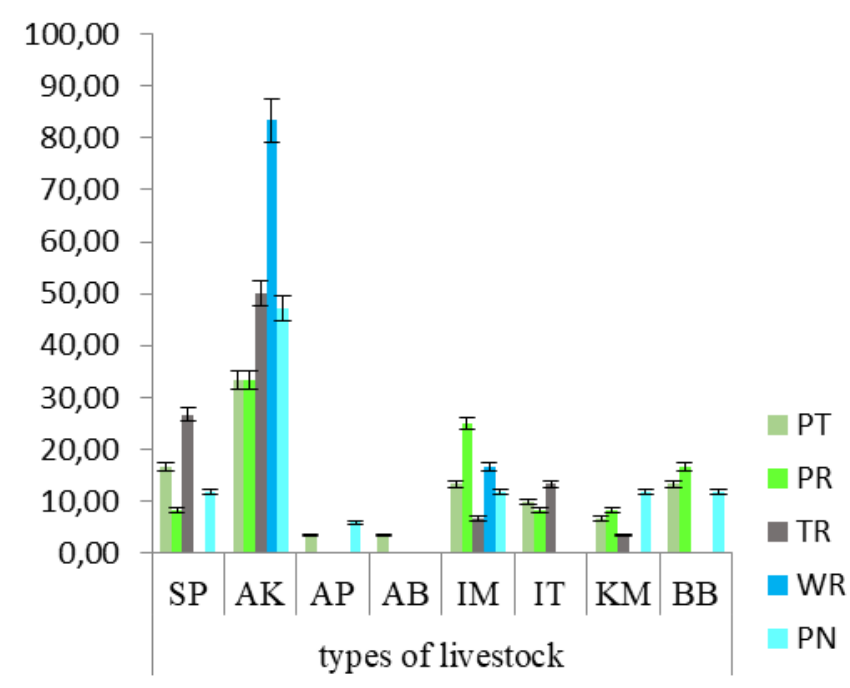

Types of SP (cattle), AK (Kampong Chicken), AP (Laying Chicken), AB (Broiler Chicken), IM (Duck Manila), IT (duck), KM (Goat), BB (Pig); Public profession of PT (Farmer and breeders), PR (Farmer), TR (breeders), WR (Entrepreneur), PN (Civil Servant).

Fig. 1. Community and livestock professions

The type of livestock in the most sought by the community in the village of Sota is $83.33 \%$ chicken, followed by $26.67 \%$ cattle, and duck manila or "entok" $25.00 \%$, and the type of livestock farming is the least layer chicken, broiler and pig respectively $3.33 \%$. According [8] farms such as poultry farms are mostly done by rural communities, either the nature of the sideline or the truly occupied as a livelihood. The average farmers and ranchers in the village sota have a productive age between 25-45 years, and long breeding between 2-15 years. The public facilities owned by the Sota Village is one of the supporting factors for the business carried out by the farmers and ranchers, namely the availability of facilities such as reservoirs as a place to provide drink for cattle and ducks, as well as the availability of special feed for cattle around the reservoir. [1] report that the availability of grass around small reservoirs is used by small ruminants as shepherding land. According to [2] reservoirs as a place for water supply for livestock, other than that small sized reservoir is also used for the provision of forage in the dry season.

Community effort related to breeder give positive impact in the form of additional income per month average reach 156,000 IDR for the type of chicken business with average sales reaching 4-5 heads per month per respondent farmers, the selling price of chicken in the Sota district on average at the age of 3-4 months reach 55.000 IDR - 65,000 IDR. According to [3], the average small-scale chicken business income per month is 115.279 IDR, the difference in income per month occurs because of the selling price of chicken in Sota district based on livestock rather than kilogram $(\mathrm{Kg})$. The process of selling livestock products made by the local community is to go around the village to offer chicken, while the sales system carried out by the community $\mathrm{x}$-transmigration is done by an online system using the existing communication media. The sales system carried out by the "Kanume" tribe community is still very simple and there is even a barter between chicken and other food ingredients.

Chicken farming business has a great opportunity to be developed in the community, but some of the obstacles faced by the village community is the emergence of various types of diseases. Therefore the need for training on the prevention and treatment of diseases in chickens conducted by the government, the percentage loss of livestock business caused by disease is high enough more than $80 \%$.

Some types of diseases that often attack chicken livestock in the community include diseases caused by viruses such as Newcastle Disease (ND), and bacteria such as Pullorum, Chronic Respiratory Disease (CRD) caused by Mycoplasma Gallisepticum, Colibaccilosis (Infection by Escherichia coli) Cholera ( Infection by Pasteruella Multocida). According to [12] the best action to prevent disease in the chicken must pay attention to biosecurity, with the aim to keep away and reduce exposure to dangerous microorganisms. In addition, treatment performed for pullorum disease in local communities generally use herbal ingredients one of them is garlic, garlic compound content that has been in the extract is able to inhibit the growth of bacteria. Highly antimicrobial properties of garlic are due to the content of allicin and diallyl sulfide contained in the essential oil of garlic. Alicin and dialyl sulfide show inhibitory activity for bacterial growth [9]. The high rate of disease affecting livestock is one of the main factors influenced by climate change and traditional maintenance patterns. Increase in fluctuating environmental temperatures affecting livestock business such as the increase of heat stress in chickens [10] in sota region caused the occurrence of bacteria and viruses that attacked many poultry. [6] that ND disease caused by many virus breeds of poultry in rural areas.

The development of local livestock business in Sota village is inseparable from the role of government and lecturer researchers in providing training on cultivation and disease prevention. The government program given to increase public interest in livestock breeding is to provide livestock assistance, according to the community report that the most widely provided assistance is local chickens and pigs. Training for local community of tribes "Kanume" by the government such as agribusiness training, fertilizer training, feed-making training, women's empowerment training, computer training and livestock farming training. Training cultivation of livestock that has been done among cultivation of cattle, goats, chickens, ducks, broiler chickens and pigs. The response of the training participants by the village Sota community in Figure 2 shows that the response of the local community, especially the tribe "Kanume" for chicken farming training get the highest percentage response of $34 \%$ followed sequentially ie cattle, duck, pig, goat and broiler $(31 \% 14 \%, 12 \%, 7 \%$ and $2 \%)$. This is in contrast to the response of the eks-transmigration 
community about the highest participant response. The percentage value related to the training is cattle breeding of $38 \%, 31 \%$ chicken, $17 \%$ duck, $8 \%$ goat, $5 \%$ broiler, and $1 \%$ pig. This participant value is high when compared to the findings of [7] which state that the response of the community in participating in training is very low, this is because the training process only uses reading media such as lifleat, which is less attractive to the public, especially those over the age of 40 year.

The change in training response is suspected because the government applies direct practice to the community so that they are more understanding and controlling. In addition, the community's response to training relates to the type of livestock given and in general that to the close relationship between the community and livestock in the area of farmers breeders in the village of Sota. [4] states that there is a relationship between livestock and humans in an integrated farming system, since livestock is closely related to the food commodities of society. In general, the whole livestock business has a positive impact on the village community, this is the main basis to provide information transfers to other villages in the border region to better the economic side with livestock business.

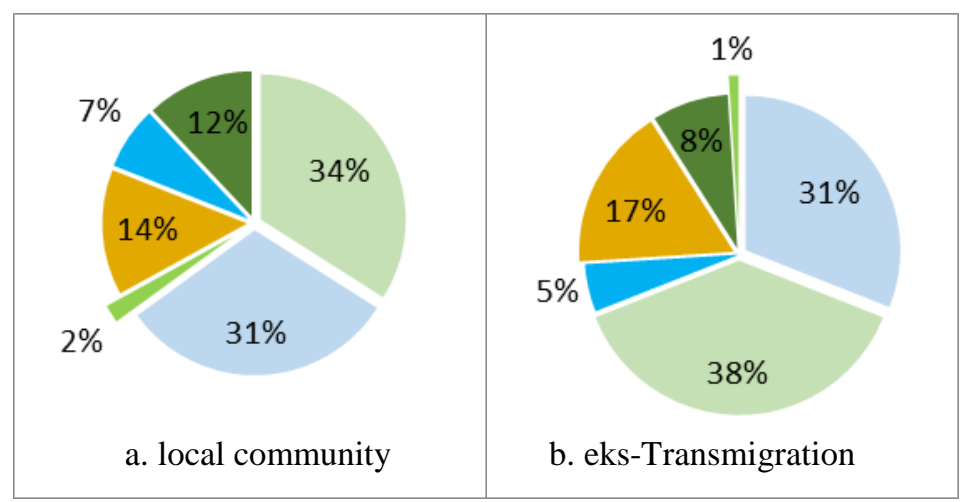

Fig. 2. Participation of the Sota village community towards training

\section{CONCLUSION}

Sota village community has the main business of farmers and breeders with the highest percentage level, in addition to the type of livestock is the most in the effort is the livestock chicken. In the tribe society "Kanume" chicken livestock business is the highest in cultivation, whereas in the community $\mathrm{x}$-transmigration, cattle cultivation is more attempted, and the business of raising pigs is done by the lowest sota villagers with traditional maintenance systems and paying attention to the environment. Average business results obtained 156,000 IDR per month for chicken business that sold 4-5 tail. Overall the livestock business helps in improving the economy of border villages sota.

\section{ACKNOWLEDGMENT}

We thank Universitas Musamus for facilities, supports, and publications

\section{REFERENCES}

[1] T.A. Amole and A.A. Ayantunde, "Assessment of existing and potential feed resources for improving," IWMI EC-IFAD, 2015.

[2] A.A. Ayantunde, O. Cofie, and J. Barron, "Multiple uses of small reservoirs in crop-livestock agro-ecosystems of Volta basin: Implications for livestock management," Agric. W. Manag., vol. 20, no. IV, pp. 81-90, 2018.

[3] R. Dewanti, G. Sihombing, "An analysis of the income of poultry farms (case study in tegalombo subdistrict, pacitan district," Bul. Peternak., vol. 36, no. I, pp. 48-56, 2012.

[4] R. Gorman, "Human-livestock relationships and community supported agriculture (CSA) in the UK," J. of Rural Stud., vol. 1, no. I, pp. 1-9, 2018.

[5] T. Maryanto, Paryono, P.S. Ernawati, Hardjosworo, and H. Setijanto, "Prospect of chicken crossing between chicken with laying race as source of poultry meat like chicken," Agric. Technol. Innov. Semin. for Rural Ind. Agribus. Dev., Ungaran, Indonesia, 2007.

[6] S. Molia, I. Traoré, B. Kamissoko, A. Diakité, M.S. Sidibé, K.D. Sissoko, and D.U. Pfeiffer, "Characteristics of commercial and traditional village poultry farming in Mali with a focus on practices influencing the risk of transmission of avian influenza and Newcastle disease," Acta Tropic., vol. 15, no. I, pp. 36 - 47, 2015.

[7] Nurcholis and I.I. Praptiwi, "The effectiveness of alternative feeding training on cattle in the dry season for villagers sota border RI / PNG," Semin. Nas. Persepsi II , Udayana, Bali-Indonesia, 2017.

[8] F.J. Nangoy and L.M.S. Tangkau, "Development of rural poultry farming program in farmer group of mawuh buras and pasawungen in pahaleten village," Natl. Semin. on Res. Results and community serv., Unmas, Bali-Indonesia, 2016.

[9] Y.F. Nuningtyas, "Effect of addition of garlic flour (Allium sativum) as an additive to the appearance of broiler production," Tropic. Livest. J., vol. 15 , no. I, pp. 21-30, 2015.

[10] W.M. Quinteiro-Filho, A. Ribeiro, J. Palermo-Neto, "Heat stress impairs performance parameters, induces intestinal injury, and decrease macrophage activity in broiler chickens," Poult. Sci, vol. 89 , no. II, pp. 1905-1915, 2010.

[11] P. Volz, P. Weckenbrock, C. Nicolas, P. Jocelyn, and Z. Dezsény, Overview of Community Supported Agriculture In Europe, France: 1 Ed. European CSA Research Group, 2016.

[12] I.W.T. Wibawan, "Major Diseases in Village Chicken and its Control Strategies,” Workshop Nas. Ungg. Lokal, Jakarta: Indonesia, 2012. 